\title{
2. Media freedom with integrity and ethics
}

\section{COMMINATARY}

In Fiji, too much damage had been done by tendentious propaganda by a few that had frayed the fabric of the Fijian society at so many levels of social harmony and political growth of a young democratic nation. And once a nation (and a person) suffers heart-attacks, it must take care of its daily diet and exercise both restraint and responsibility. This is never more important than during an election. This commentary argues that freedom of the press, academic freedom and parliamentary privilege, are advanced and strengthened by those who practise these with professional ethics and personal integrity and conscientiously deepen public trust, individually and collectively. When the institutions are diminished, everybody is diminished.

SATENDRA NANDAN

Founding chair, Fiji Media Industry Development Authority (MIDA)

$\mathrm{I}$

THE political maelstrom that Fiji's islands and individuals have endured over the past couple of months, more than freedom of the press has taken a severe battering. And not always for the better.

In the past 27 years, Fiji has suffered coups: the worst and the best, as far as coups go. Those of us who care in our own ways for the beloved islands, and who love the island-nation because of its unnecessary suffering, know the price our people have had to pay in shattered lives and broken homes; but more than ever they also share a common destiny.

Many personal and family tragedies have touched and impinged on the national collective consciousness. All happy families, wrote Leo Tolstoy, resemble one another, but every unhappy family is unhappy in its own way. This is true of nations too for in a larger sense a nation is a family.

There are, however, experiences of which even the great Russian novelist, the unrivalled author of War and Peace, was unaware. For example, it's been said that no poetry is possible after the Holocaust, or the bombing of Hiroshima and Nagasaki. And yet the human heart beats with hope and the human imagination 
continues to create: the birds sing in the trees of Hiroshima and new structures are built on the ruins of the Twin Towers. In Fiji's new Constitution it's beautifully and uniquely expressed: 'Freedom of imagination and creativity'.

You might think these human happenings have nothing to do with Fijisometimes missing on the world map; often seen as only two tiny dots or drops in the vast Pacific.

Fiji is, in my opinion, a microcosm of human ills and goodness, of pain and possibilities in a people: archaic in some ways, modern in many ways. Where else in the South Pacific will you find a people of such variegated vitality, humanity and a healthy sense of humour. When the warning of a tsunami is given, many drive to the shore to see if it's coming!

After every cyclone, they rebuild and replant. After every coup, they have a new constitution and elections. People vote in large numbers as if nothing had dented their faith in the inherent dynamics of democracy in the most intimately intertwined multicultural nation of our region.

A small nation that has been through these heart-attacks and heart-aches surely deserves fresh air of freedom and responsibility of the highest kind and deepest understanding and respect.

And it's nowhere more visible than in the pages of our newspapers, magazines and the sounds and images of the audio-visual media.

Recently two international cases in journalism make the point tellingly: Peter Greste, an Australian citizen and a television journalist with Al-Jazeera, has been jailed for seven years, for allegedly supporting the ousted Mohammed Morsi's Muslim Brotherhood - a party that used the freedom of democracy to gain power and, once in power, began dismantling the structures that support and sustain democracy and its infinite variety and voices. The Arab Spring of hope turned into a long winter of despair for many citizens. Many died.

The military intervened. So far, no American leader or a European statesman has called it a coup, as far as I know. So there are coups and coups as there are wars and wars: just and unjust.

Greste became a caged victim of the oily, mercenary, messy politics of the Middle East. The international outrage will eventually free an Australian citizen; what happens to his Egyptian colleagues jailed with him is quite another matter (Peter Greste: Egypt envoy hopes, 2014).

The other case, in the heart of England, is of Andy Coulson, the sometime media director of the British Prime Minister David Cameron. Coulson was also the former editor of now defunct News of the World owned by the media 
mogul, Rupert Murdoch, known in Fleet Street as the 'dirty digger' from Down Under. ${ }^{1}$ Often his paper did dig deep - mainly dirt.

Murdoch has the reputation of making prime ministers and breaking governments with the power of his press. This is flaunted as the freedom of the press by the many pampered journalists in his Augean stables.

One can question the judgement of Prime Minister Cameron, but few will disagree with the judgement of the distinguished judge, Justice Saunders, who jailed a rogue journalist. Andy Coulson has been jailed for breaking the law under the nose of Fleet Street, which once symbolised freedom of the press, next to the House of Commons, the mother of parliaments (Andy Coulson jailed, 2014).

What we should be asking is: How was this freedom used? And abused? And to what purpose? And how well the public interest was served or public trust betrayed? We live in a society supported by these structures and if the salt loses its saltiness wherewith shall it be salted?

There's nothing like absolute freedom-your freedom extends to the tip of your forefinger but it ends at the tip of my nose.

In short, there's no freedom of any kind without an equal sense of responsibility and the recognition of another's liberty and respect for privacy.

When I was a young journalist in New Delhi on The Statesman, my favourite readings were the daily Manchester Guardian, a weekly magazine New Statesman and a monthly magazine aptly named Encounter.

The Guardian's great editor, C. P. Scott, enunciated his paper's philosophy: 'Comment is free but facts are sacred.'

In that simple sentence is summed up the sacred duty, professional ethics and the sense of responsibility of the journalist. Seven years from now the Guardian will be celebrating its bicentennial-a fabulous achievement. And, like Johnnie Walker, still going strong without losing its unique blend of malt whiskies so popular in Fiji.

Our own first local daily in Fiji was founded in 1869. Few newspapers in a small colony enjoyed such monopoly of freedom and power for more than a century.

A few years ago when the Bainimarama government changed the rules of media ownership there was quite a hue and cry - and yet media ownership is in Australia a major political and moral issue.

The government's central thrust was that journalists and the media must

PACIFIC JOURNALISM REVIEW 20 (2) 201419 


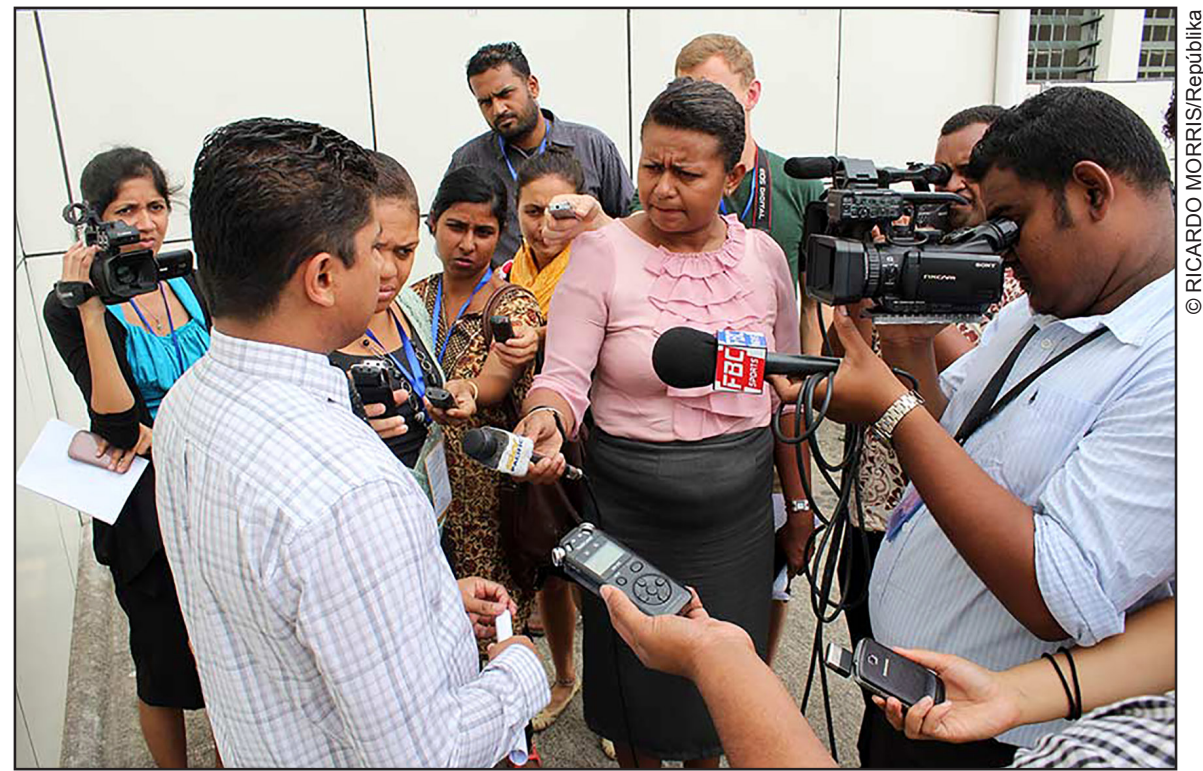

Figure 1: Journalists talked to the Fiji Supervisor of Elections, Mohammed Saneen, on 8 September 2014.

take proper responsibility for what they feed the public they purport to inform and serve. They must write under their byline, which meant serious research, checking of facts and writing. The greater the power, the greater the responsibility.

In Fiji, too much damage has been done by tendentious propaganda by a few that has frayed the fabric of the Fijian society at so many levels of social harmony and political growth of a young democratic nation.

And once a nation (and a person) suffers heart-attacks, it must take care of its daily diet and exercise both restraint and responsibility. This is never more important than during an election.

In a pertinent case in the recent Indian elections, a major political figure was banned from campaigning for making false claims against another party's political platform. Personal vindictiveness was the man's main motive, not political philosophy of any consequence.

The Election Commission intervened - winning an election on false premises or promises is just dishonest practice and corrupt politics. The leader was prevented from campaigning until investigations were completed. 
In fact, the Fijian Electoral Commission can stipulate that a party or an individual who wins a seat on falsification of facts available to the public, should and could be deprived of their seat after a judicial review finds that party or person guilty as charged. This, I think, will add credibility to the election process and will certainly act as a deterrent to unscrupulous demagogues.

Here's a case of some relevance: I've been reading lately that the leader of a political party has been saying the native land tenure in Fiji is in jeopardy. Is this true? What are the facts? Creating false fears is politically more heinous a crime than taking undeclared donations.

One has to read the preamble of the new Fiji Constitution to understand how far from the truth this politically bankrupt leader's pronouncements and assertions. And yet this party has the privilege of fighting the election on this very Constitution.

The land issue has been so falsely and fallaciously used in Fiji for so long that it's no longer funny: the Electoral Commission has the power, I think, to put an end to this kind of lurid and ludicrous propaganda.

It helped make this election more exhilarating and exciting when it could make the candidates think and get out of their ghettoes of race, religion, communalism, fear-mongering, using corrupt and corrupting strategies.

A journalist has the freedom to report but also to show to the reader and the listener the truth of the reportage.

Journalism is not a crime but journalists should not be criminals either, as Andy Coulson's case rather disgracefully illustrates. The criminal then becomes the news of the world.

A journalist should always remember the occupational hazards of his or her profession (to paraphrase the old forecaster's lament):

Among life's dying embers

These are my regrets:

When I'm right no one remembers

When I'm wrong no-one forgets.

Freedom of the press, academic freedom and parliamentary privilege, are advanced and strengthened by those who practise these with professional ethics and personal integrity and conscientiously deepen public trust, individually and collectively.

When you devalue the institutions, we're all diminished. 


\section{'FAILED' STATES AND THE ENVIRONMENT}

\section{Notes}

1. Murdoch's Sydney-based News Limited owned the Fiji Times Limited until forced to divest its shares under the Fiji Media Industry Development Decree 2010 which restricted foreign ownership of a news media company to 10 percent. The local Motibhai Group bought out the News Limited interest.

\section{References}

Andy Coulson jailed for 18 months for conspiracy to hack phones (2014, July 4). The Guardian. Retrieved on September 11, 2014, from: www.theguardian.com/ uk-news/2014/jul/04/andy-coulson-jailed-phone-hacking

Peter Greste: Egypt envoy hopes for release 'sooner rather than later' (2014, September 10). The Guardian. Retrieved on September 11, 2014, from: www. theguardian.com/media/2014/sep/11/peter-greste-egypt-envoy-release-sooner

Dr Satendra Nandan is emeritus professor at the University of Canberra's Centre for Creative and Cultural Research. He is a Fiji author and former politician and cabinet minister. He is currently writing a book on his political and literary experiences of Fiji, India and Australia. His most recent book, Nadi: Memories of a River, was published in July. This article was originally published in Repúblika magazine in Fiji.

Satendra.Nandan@canberra.edu.au 